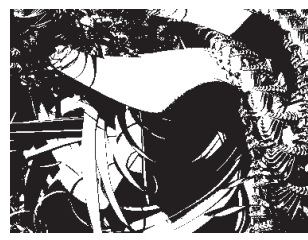

\title{
POLOŽAJ CRKAVA I VJERSKIH ZAJEDNICA I OSTVARIVANJE VJERSKIH SLOBODA U USTAVIMA SRBIJE
}

Dragan NOVAKOVIĆ

Ministarstvo vjera Srbije, Beograd

UDK: 342.724(497.11)

$322(497.11)$

Pregledni rad

Primljeno: 9. 7. 2009.

Predstavljene su odredbe Ustava Srbije kojima se uređuje položaj crkava i vjerskih zajednica te ostvarivanje vjerskih sloboda u modernoj srbijanskoj državnosti, uključujući i ustavne akte relativno dugih razdoblja kada je Srbija bila uključena u razne oblike jugoslavenskih zajednica. Kompletni proces donošenja Ustava smješten je u širi društveno-povijesni kontekst iz kojega se mogu sagledati napori srbijanske političke $\mathrm{i}$ intelektualne elite da tijekom skoro dva stoljeća pronađu najbolii državni oblik koji će se temeliiti na demokratskim principima i omogućiti stalni ekonomski uspon i kulturni razvitak. Analizom originalnih ustavnih tekstova nedvosmisleno je potvrđen neprekidni napredak vjerskih sloboda, koji se kretao od elementarne mogućnosti za prakticiranje vlastite religije, preko utvrđivanja državnoga položaja Srpske pravoslavne crkve i prava drugih vieroispovijedi na potpuno slobodno i zaštićeno djelovanje do usuglašavanja ustavnih odredaba u toj osjetliivoj oblasti s najvažnijim dokumentima međunarodnoga prava i praksom Europske unije. Poduzetim istraživanjem ustavnih dokumenata i konkretnih uvjeta u kojima je djelovala srbijanska država samostalno ili u zajednici s drugima prikazan je jedan od najvažnijih razdoblja srbijanske povijesti, na početku kojega je despotija zasnovana na orijentalnim vrijednostima i bez institucionalnih mehanizama da zaštiti osnovno pravo pojedinca na život, a na kraju neovisna država opredijeljena da, slijedeći najbolje demokratske tradicije, svoju budućnost gradi u okviru Europske unije.

Ključne riječi: Srbija, Jugoslavija, ustavi, vjerske slobode, crkve, vjerske zajednice 
Zahvaljujući rezultatu referenduma održanog u Crnoj Gori 21. svibnja 2006. godine, Srbija je ponovno postala neovisna, što je na simboličan način značilo vraćanje u 1918. godinu, kada je svoju međunarodno priznatu neovisnost na Berlinskom kongresu 1878. godine ugradila u novu državu, Kraljevinu Srba, Hrvata i Slovenaca. Promijenjene okolnosti zahtijevale su donošenje novoga Ustava zbog zamjene onoga iz vremena jednopartijskoga sustava. Čvrsti mehanizmi predviđeni za promjenu staroga Ustava, koji su podrazumijevali kvalificirani referendum i dvotrećinsku skupštinsku većinu, tražili su od svih aktera na političkoj sceni Srbije da čine kompromise i razne vrste ustupaka.

Samostalna država zatekla je nespremnom i srbijansku intelektualnu elitu, koja je više od sedamdeset godina svoje potencijale usmjeravala na proučavanje i afirmaciju sveukupnoga jugoslavenskoga naslijeđa. Izašavši iz faze nesnalaženja, uvjetovane i neminovnošću okončanih povijesnih procesa na jugoslavenskim prostorima, započinje sveobuhvatno izučavanje dostignuća moderne srbijanske državnosti od 1804. do 1918. godine. Najveća pozornost posvećuje se drugoj polovici XIX. stoljeća, odnosno razdoblju u kojemu je srbijanska država institucionalno sređena, formirane su sve najvažnije nacionalne kulturne ustanove, sustavno razvijeno školstvo, uspostavljena moderna vojska, doneseni prvi zakoni prema europskim uzorima i otpočeo je razvitak kapitalističkih robno-novčanih odnosa.

Važno mjesto u proučavanjima zauzima i povijest prava, tako da pojedini rezultati pokazuju da se iza arhaičnoga jezika i starosti od sto i više godina kriju akti s iznenađujućom modernošću. Slijedeći ta nastojanja, proistekao je i ovaj rad, s ciljem da predstavi položaj Crkava i vjerskih zajednica te ostvarivanje vjerskih sloboda u svim ustavima od Sultanskoga hatišerifa (Sultanove povelje, op. prev.) iz 1830. godine do Ustava Republike Srbije iz 2006. godine. Poštujući povijesne okolnosti i sedamdesetogodišnje postojanje dviju Jugoslavija i Državne zajednice SCG, $\mathrm{u}$ rad su uključeni i ustavi doneseni u tom razdoblju.

\section{KRALJEVINA SRBIJA}

\section{Hatišerif iz 1830. godine}

Nakon uspješno završenih borbi tijekom Drugoga srbijanskog ustanka (1813. - 1815.) i uspostavljanja primirja, knez Miloš je još petnaestak godina nizom pažljivo odabranih postupaka nastojao ostvariti što veći stupanj državne samostalnosti u odnosu na Portu i osigurati autonomiju Pravoslavne crkve u Sr- 
DRUŠ. ISTRAŽ. ZAGREB GOD. 20 (2011), BR. 2 (112)

STR. 517-539

NOVAKOVIĆ, D. POLOŽAJ CRKAVA.. biji od "Vaseljenske patrijaršije". Srbijanske deputacije tražile su od Porte da osigura slobodu bogoslužja, nesmetano obavljanje vjerskih obreda, podizanje i popravak crkava i manastira te uporabu crkvenih zvona. Zahvaljujući pritisku ruske diplomacije, sultan se obvezao izdati poseban hatišerif o autonomiji Srbije (Ćorović, 1989., 66-70).

Usuglašeni hatišerif o unutarnjoj političkoj samoupravi pod vrhovnim suverenitetom sultana izdan je 3. kolovoza 1830. godine. Formulirajući odredbe hatišerifa, Porta nije pokazala spremnost prihvatiti srpske zahtjeve i detaljno urediti odnose između Srbije i "Vaseljenske patrijaršije", zastupajući stajalište da su takvom aktu primjerenija opća načela o slobodi vjeroispovijedi i načinu izbora višega klera, a da pitanje međusobnih odnosa rješavaju zainteresirane strane. Pridržavajući se tog opredjeljenja, hatišerif $u$ točki 1 . potvrđuje i jamči pravo na slobodno obavljanje kanonima propisanih bogosluženja. Točkom 14. djelomično se napušta zauzeti neutralizam i izlazi ususret srbijanskim zahtjevima, jer je određeno da će metropolite i episkope odabrane od naroda "vaseljenski patrijarh" potvrđivati bez obveze da dolaze u Carigrad (Gavrilović, 1912., 606).

Pravilno procijenivši da su ograničenja utvrđena hatišerifom u osnovi suglasna s kanonskim poretkom i da je politička autonomija preduvjet za ustrojstvo samostalne Crkve, knez Miloš je poveo pregovore s "Vaseljenskom patrijaršijom". Nakon iskazane spremnosti srbijanske strane da ispuni određene uvjete, "vaseljenski patrijarh" je u rujnu 1831. godine sa Sinodom izdao Akt o autonomiji Crkve u Srbiji. Dobivši uvjeravanja kneza Miloša o sigurnoj isplati zaostalih eparhijskih dugova, patrijarh je akt u uobičajenoj formi konkordata uputio u Srbiju u siječnju 1832. godine. ${ }^{1}$

\section{"Sretenjiki ustav" iz 1835. godine}

Upravljajući državom potpuno samostalno i nespreman dijeliti vlast i trpjeti tuđe utjecaje, knez Miloš je neovisno o velikim državnim i nacionalnim uspjesima neprekidno stvarao i žestoku oporbu. Nakon jedne seljačke bune dogovoreno je da se o Sretenju (blagdan Svijećnice) sazove sabor na kojem bi se donio Ustav i u skladu s njegovim odredbama ograničila kneževa vlast. Sastavljen je tekst po ugledu na slobodoumne ustave Švicarske i Belgije, koji je usvojen 14. veljače 1835. godine. Liberalni karakter i činjenica da se država, bez svih atributa samostalnosti, odlučila za takav postupak doveli su do osporavanja velikih sila, što je omogućilo knezu da donese odluku o ukidanju Ustava (Janković, 1985.).

Neovisno o činjenici da je "Sretenjski ustav" vrijedio samo dva tjedna i ocjene nekih teoretičara o "francuskom zasa- 
DRUŠ. ISTRAŽ. ZAGREB GOD. 20 (2011) BR. 2 (112),

STR. 517-539

NOVAKOVIĆ, D. POLOŽAJ CRKAVA... du u turskoj šumi", treba upozoriti na odredbe poglavlja devet, kojima je prvi put najvišim državnim aktom uređen položaj Crkve u Srbiji. Ćlanak 92. propisuje da Pravoslavna crkva ima samo jednoga metropolita, dok broj episkopa ovisi o potrebama naroda. Unutarnje rukovođenje Crkvom, prema članku 93., obavlja metropolit i duhovna vlast, koja će biti određena ukazom na način predviđen u sporazumu potpisanim s "vaseljenskim patrijarhom". U skladu s člankom 94., metropolit i arhijereji primat će plaću iz državne blagajne, dok isti članak utvrđuje obvezu raspoređivanja svećenika samo na slobodne parohije. Ustav u članku 95. propisuje obvezu naroda da svećenstvu i monaštvu redovito daje propisane dažbine. Viši kler je neovisan, ali članak 97. omogućuje knezu i državnom sovjetu da na konsultacije o crkvenim pitanjima poziva metropolita i episkope. Slobodoumnost i demokratičnost Ustava posebno su došli do izražaja u člancima 97. i 98., koji propisuju da svaka vjeroispovijed u Srbiji može slobodno obavljati obrede pod pokroviteljstvom srbijanske Vlade i da se zaklinjanje ljudi koji ne pripadaju Pravoslavnoj crkvi obavlja po propisima njihove vjere (Ustav Knjažestva Serbije - 1835., 1988.).

\section{Ustav iz 1838. godine}

Zadovoljan zbog neuspjeha ustavnog eksperimenta, kojemu je osnovni zadatak bio ograničenje njegove moći, knez Miloš je ipak morao dati obećanje o brzoj izradbi i usvajanju novog ustava. Uvjeren da takav akt može biti zapreka njegovu načinu vladavine, knez je odgađao pripreme i tako jačao opoziciju deklariranu kao ustavobranitelji. Komisija, u kojoj su uz ruske i turske predstavnike dominirali Miloševi politički protivnici iz Srbije, uspješno je završila rad u Carigradu, što je omogućilo proglašenje novoga Ustava 10. prosinca 1838. godine. Osnovna karakteristika novoga teksta jest osjetno nazadovanje u odnosu na hatišerif iz 1830. godine, jer je ponovno potvrđena mogućnost miješanja Turske u unutarnje poslove Srbije i direktno kreiranje njezine uprave kroz pravo sudjelovanja u donošenju ustava (Ćorović, 1989., 79).

Novi Ustav na uopćeniji i načelniji način regulira vjersku problematiku, dajući prevlast slobodi vjeroispovijedi u odnosu na očekivano utvrđivanje položaja Pravoslavne crkve, episkopata i svećenstva u Srbiji. Započinjući članak 57., koji je u cijelosti posvećen tim pitanjima, tvorci Ustava konstatiraju da su Srbi platežni podanici Porte i kršćani grčke vjere koju predstavlja Istočna crkva. Suglasno tom opredjeljenju, sultan daruje srbijanskom narodu punu slobodu obavljanja obreda prema vlastitu zakonu, kao i pravo da zajedno s knezom bira metropolite i episkope. Utvrđujući navedena prava, sultan istodobno obvezuje izabrani viši kler na podčinjenost duhovnoj 
DRUŠ. ISTRAŽ. ZAGREB GOD. 20 (2011), BR. 2 (112)

STR. 517-539

NOVAKOVIĆ, D. POLOŽAJ CRKAVA. vlasti patrijarha u Carigradu. Zahvaljujući slobodama ranije darovanim kršćanima u Osmanskom Carstvu, episkopat upravlja poslovima vjere i Crkve pod uvjetom da takva djelatnost isključi svaku aktivnost političke prirode. U skladu sa zajamčenom upravom, narod nagrađuje svoj viši kler, svećenstvo i monaštvo te pomaže crkvene zavode. Člankom 58. višem je kleru dano pravo okupljanja radi donošenja zakona i rješavanja svih crkvenih pitanja. Načelnicima okružja člankom 65 . zabranjeno je miješanje u crkvene poslove i određeno da pružaju zaštitu i da se brinu o crkvenoj imovini. Po članku 22., ministru pravosuđa povjereno je dopisivanje s crkvenom upravom i dano pravo uređivanja pitanja u svezi s vjerom, bogosluženjem i crkvom (Ustav Knjažestva Serbije, tj. Sultanski hatišerif - 1838., 1988.).

Odredbe Ustava nazvanog "turski" iznenadile su kneza Miloša, koji nije očekivao da će njegova vlast do te mjere biti oslabljena i kontrolirana. Uvidjevši uzaludnost otpora, nespreman trpjeti stalne pritiske i očekujući mogućnost najgorega, 13. lipnja 1839. godine napustio je Srbiju. Njegovim silaskom s vlasti započela je nova era u povijesti Srpske crkve, koja se morala prilagođavati novonastalim prilikama i promijenjenom načinu vladavine nove i drukčije političke elite.

\section{Ustav iz 1869. godine}

Ojačani povlačenjem kneza Miloša, sovjetnici su - dobivši status "ustavobranitelja" - izazvali 1842. godine dinastičku krizu, koja je završila izborom Aleksandra Karađorđevića za kneza. Manjkavosti "Turskog ustava" nisu značile zapreku za otpočinjanje procesa europeizacije države, jačanja ekonomije i uspostavljanja zakonitosti kao protuteže kneževoj samovolji. Proistekao iz kulminacije institucionalne krize utjelovljene $\mathrm{u}$ nekoj vrsti dvovlašća između kneza te otuđenoga i birokratiziranoga Sovjeta i sveopćega narodnog nezadovoljstva, sazvan je sabor na kojem je potkraj 1858. godine zbačen knez Aleksandar, promijenjena dinastija i za vladara vraćen knez Miloš. Nošen svojom u osnovi starom vizijom načina vladanja, suspendirao je Ustav iz 1838. godine, ukinuo zakone iz doba ustavobranitelja i marginalizirao Sovjet. Nakon dviju godina provedenih na prijestolju, naslijedio ga je sin Mihailo, čiju je vladavinu karakterizirao osobni apsolutizam, što je dovelo do organiziranja urote u kojoj je ubijen u lipnju 1868. godine.

Malodobnoga kneza Milana zamijenilo je u obavljanju vladarskih ovlasti namjesništvo, koje je u prioritete rada uključilo i izradbu novoga ustava s ciljem transformiranja policijskom torturom obilježene vladavine u ustavnu, s predstavničkom vladom. Veliki narodni sabor usvojio je lipnja 1869. godine u 
DRUŠ. ISTRAŽ. ZAGREB BR. 2 (112)

STR. 517-539

NOVAKOVIĆ, D. POLOŽAJ CRKAVA... GOD. 20 (2011)

Kragujevcu prvi put potpuno samostalno, tekst što ga je pripremio reprezentativni odbor. Pokazalo se da je to najdugotrajniji srbijanski ustav u XIX. stoljeću (Ustav od 1869. godine, 72).

Položaj Crkve definiran je u članku 31., iz kojega proizlazi da je vladajuća vjera u Srbiji istočnopravoslavna. Isti članak jamči slobodu svih drugih priznatih vjera i zakonsku zaštitu prilikom obavljanja obreda. Poziv na propise vjere ne oslobađa pojedinca obveze ispunjavanja građanskih dužnosti. Zabranjeno je poduzimanje postupaka nepovoljnih (prozelitizam) za pravoslavnu vjeru. Osmi odjeljak Ustava posvećen je crkvama, školama i dobrotvornim zavodima, tako da članak 119. jamči slobodno i javno provođenje obreda svih vjeroispovijedi priznatih u Srbiji, uključujući i one čija će legalnost proisteći iz posebnih zakona. Zaštitnik priznatih vjeroispovijedi u državi jest knez. Nadzor nad duhovnim tijelima svih vjeroispovijedi ima ministar crkvenih poslova, dok uprava unutarnjih vjeroispovijednih poslova, kada je u pitanju Pravoslavna crkva, pripada Arhijerejskom saboru. Za ostale Crkve i vjerske zajednice ustavima i drugim propisima utvrđene su duhovne vlasti. Cjelokupno dopisivanje Pravoslavne crkve s vlastima ili saborima izvan zemlje može se voditi uz odobrenje ministra crkvenih poslova. Svećenici drugih vjeroispovijedi korespondenciju s crkvenim tijelima u inozemstvu podnose na odobrenje ministru crkvenih poslova. Ako duhovna vlast izvan zemlje uputi neki akt, mjerodavno crkveno tijelo može ga proglasiti nakon odobrenja ministra crkvenih poslova. Žalbe protiv zloporaba duhovnih vlasti priznatih vjeroispovijedi podnose se ministru crkvenih poslova. Građanski poslovi i imovinski sporovi svećenika, prema članku 123., rješavaju se na temelju državnih zakona (Ustav za Knjažestvo Srbiju - 1869., 1988.).

\section{Ustav iz 1888. godine}

Namjesnička uprava Srbijom formalno je završena kolovoza 1872. godine, kada je knez Milan navršio 18 godina. Osnaživši svoju poziciju, mladi se knez aktivnije uključuje u vođenje zemlje, što je dovelo do oštrih stranačkih sukobljavanja i čestih smjena vlada raznih političkih orijentacija. Položaj kralja Milana stalno se pogoršavao, tako da je, neovisno o međunarodnom priznanju Srbije na Berlinskom kongresu, bio prinuđen prijeći u defenzivu i činiti ustupke političkim protivnicima. Uspostavljeni Veliki ustavotvorni odbor uspješno je završio rad, što je omogućilo Narodnom saboru da 22. prosinca 1888. godine izglasa moderan i napredan Ustav (Jovanović, 1905.).

Prema članku 3. Ustava, u Kraljevini Srbiji državna je vjera istočnopravoslavna. ${ }^{2}$ Srpska je crkva autokefalna i ne ovisi o drugim stranim Crkvama, ali održava dogmatsko jedinstvo s "Vaseljenskom patrijaršijom". Sloboda savjesti je, u skladu s 
DRUŠ. ISTRAŽ. ZAGREB GOD. 20 (2011), BR. 2 (112)

STR. 517-539

NOVAKOVIĆ, D. POLOŽAJ CRKAYA.

člankom 18., neograničena. Priznate su vjere slobodne i pod zaštitom zakona, ako njihovi obredi ne vrijeđaju javni red ili moral. Zabranjuje se svaka radnja (prozelitizam) usmjerena protiv Pravoslavne crkve u Srbiji. Državljani Srbije ne mogu biti oslobođeni od građanskih i vojnih dužnosti pozivanjem na propise svoje vjere. Članak 41. utvrđuje da kralj i njegov dom moraju biti pravoslavne vjere, a 42 . da je vladar zaštitnik svih priznatih vjeroispovijedi u Srbiji. Unutarnja uprava Pravoslavne crkve, prema članku 190., pripada Arhijerejskom saboru, a kada su u pitanju druge vjeroispovijedi, njihovim mjerodavnim tijelima. Ministar prosvjete i crkvenih poslova ima nadzor nad duhovnim vlastima Pravoslavne crkve i svih drugih priznatih vjeroispovijedi. Ustrojstvo crkvene vlasti i bogoslovskih škola Pravoslavne crkve uređuje se zakonom u dogovoru ministra s Arhijerejskim saborom. Prema članku 191., crkvene vlasti sude svećenicima za krivnje počinjene prilikom obavljanja dužnosti, dok se za ostale prijestupe kažnjavaju po kaznenom zakonu. Žalbe protiv zloporaba crkvenih vlasti bilo koje vjeroispovijedi u zemlji podnose se ministru crkvenih poslova. Svećeničke osobe i crkvene ustanove, u pogledu građanskih i imovinsko-pravnih odnosa, podčinjene su državnim zakonima. Dopisivanje duhovnih tijela Pravoslavne crkve s inozemnim crkvenim saborima i sinodima, prema članku 192., teče uz odobrenje ministra prosvjete i crkvenih poslova. Kada je u pitanju službena korespondencija drugih vjeroispovijedi $u$ Srbiji s crkvenim vlastima $u$ inozemstvu, mora se podnositi na uvid i odobrenje ministru prosvjete i crkvenih poslova. Službena pisma ili naredbe crkvenih vlasti, sabora i sinoda izvan zemlje ni jedna crkvena vlast u Srbiji ne može objaviti ili izvršiti bez znanja i odobrenja ministra crkvenih poslova (Ustav za Kraljevinu Srbiju - 1888., 1988.).

\section{Ustav iz 1903. godine}

Političke promjene do kojih je došlo nakon ubojstva kralja Aleksandra i kraljice Drage 1903. godine i dolaska na vlast dinastije Karađorđevića nisu posebno utjecale na položaj Crkava i vjerskih zajednica. ${ }^{3}$ Novi Ustav od 7. lipnja 1903 . godine preuzeo je $\mathrm{u}$ cijelosti rješenja iz Ustava od 1888. godine, koja se odnose na Srpsku crkvu i ostale priznate vjeroispovijedi (Ustav za Kraljevinu Srbiju - 1903., 1988.).

\section{Pravni položaj ostalih Crkava i vjerskih zajednica}

Sultanski hatišerif i Ustav iz 1838. godine uređuju položaj Pravoslavne crkve, dok se odredbe Sretenjskoga ustava o pravu svake vjeroispovijedi na slobodno obavljanje obreda, zbog 
DRUŠ. ISTRAŽ. ZAGREB GOD. 20 (2011) BR. 2 (112),

STR. 517-539

NOVAKOVIĆ, D. POLOŽAJ CRKAVA...
Srbija je bila obvezna poštivati sustav uspostavljen u Osmanskom Carstvu 1766. godine, po kojem su službeno postojali islamski, grčki, katolički, židovski te dva armenska mileta-naroda (Ekmečić, 1989., 37). Hatišerifom od Gilhane, koji je 1839. godine izdao sultan Abdul Medžid, proglašena je sloboda i ravnopravnost svake vjeroispovijedi i formirano posebno carevinsko vijeće (Tanzimat), u koje su ušli i predstavnici kršćana (Veselinović, 1966., 172).

Provodeći reformu cjelovitoga državnog sustava, knez Aleksandar i ustavobranitelji usvojili su 9. rujna 1853. godine tri zakona o slobodi vjere, zaštiti Pravoslavne crkve i pravima Katoličke crkve. Prvi zakon potvrđuje slobodu Katoličke crkve i drugih kršćanskih vjera, drugi definira zabranu prelaska iz pravoslavlja i status djece iz mješovitih brakova, dok treći dopušta osnivanje katoličke općine, podizanje crkve, formiranje zasebnoga groblja te postavljanje svećenika (Wagner, 1933., 299-301).

Pariškim mirom iz 1856. godine, kojim je završen Krimski rat, Srbija je obvezna osigurati slobodu vjeroispovijedi. U skladu s tim, 1858. godine donesen je zakon koji luteranima osigurava osnovna vjerska prava (Wagner, 1933., 305-306). Ukazom kneza Miloša o ravnopravnosti građana iz 1859. godine, priznata je ravnopravnost židovske zajednice. Zakon o vakufskim posjedima usvojen je 1863. godine, a ukazom kneza Mihaila Obrenovića iz 1868. godine Srbija je službeno priznala slobodu ispovijedanja islamske vjere (Novaković, 2003., 43). Prava zajamčena Ustavima iz 1869. i 1888. godine odnose se na naznačene Crkve i vjerske zajednice, a njihov je položaj dopunski ojačan odlukama Berlinskoga kongresa, koji je državnu neovisnost Srbije uvjetovao poštivanjem vjerskih sloboda.

Procjenjujući značenje Vatikana u međunarodnim odnosima i nastojeći da katoličkim vjernicima na jugoslavenskim prostorima pošalje jasnu poruku o spremnosti na suradnju i toleranciju, Vlada Srbije i njezin predsjednik Nikola Pašić uložili su velike napore da položaj malobrojne katoličke zajednice urede konkordatom. Nakon višegodišnjih pregovora potpisan je Konkordat sa Svetom Stolicom, koji je Narodni sabor Srbije ratificirao uoči izbijanja svjetskoga sukoba 26. lipnja 1914. godine, a Vatikan tek nakon duga oklijevanja i procjene situacije u proljeće 1915. godine (Novaković, 2002.).

\section{KRALJEVINA JUGOSLAVIJA}

Crkve i vjerske zajednice zadržale su isti pravni položaj kao u zemljama koje su ušle $u$ sastav nove države od stvaranja Kraljevine SHS 1. prosinca 1918. godine do usvajanja prvog Ustava 28. lipnja 1921. godine. ${ }^{4}$ Postojanje brojnih nacija i religija odlučujuće su pridonijeli da regent Aleksandar već 6 . 
DRUŠ. ISTRAŽ. ZAGREB GOD. 20 (2011), BR. 2 (112)

STR. 517-539

NOVAKOVIĆ, D. POLOŽAJ CRKAVA. siječnja 1919. godine izda Proklamaciju kojom se jamči ravnopravnost svih vjera u Kraljevini i potvrđeno eliminiranje povlaštenoga položaja i državnoga statusa Pravoslavne crkve u Srbiji i Crnoj Gori, dogovoreno Krfskom deklaracijom (Troicki, 1935., 13). Složena međunacionalna i međukonfesionalna situacija u novoj državi utjecala je na savezničke sile da Privremenim zakonom od 10. svibnja 1920. godine obvežu Kraljevinu SHS da svim stanovnicima osigura pravo na slobodno javno i privatno obavljanje obreda za svaku religiju. ${ }^{5}$

Ovi spisi upućivali su na mogućnost da Ustavotvorni sabor prihvati načelo odvojenosti Crkve od države i tako na jedinstven način riješi zatečeno heterogeno stanje u pravnom položaju konfesionalnih zajednica u novoj državi. ${ }^{6}$ Ustav od 28. lipnja 1921. godine jamči slobodu vjere i savjesti, napušta sustav državnih Crkava, ali dosljedno ne provodi načelo o odvojenosti vjerskih zajednica od države. Vjerske zajednice dobile su status "javnih ustanova sa specijalnim položajem u državi i posebnim privilegijama" i ovlastima da uime države obavljaju neke javno-pravne poslove (Stefanović, 1953., 101).7 Vidovdanski ustav, a slična rješenja zadržao je i tzv. Oktroirani ustav od 31. rujna 1931. godine, provodi podjelu na usvojene i priznate vjerske zajednice. Položaj usvojenih dobile su sve vjerske zajednice koje su bile zakonski priznate u bilo kojem dijelu koji je ušao u sastav Kraljevine. Status priznatih proizlazio je iz naknadnoga zakonskog priznanja od tijela nove države. ${ }^{8}$ Jedna skupina autora smatra da su taj status imale Srpska pravoslavna crkva, Katolička s Grkokatoličkom, Evangelička, Reformirana, Baptistička, Metodistička, Nazarenska, Starokatolička, Islamska i Židovska. ${ }^{9}$ Prema drugom stavu, usvojene i priznate bile su Srpska pravoslavna crkva, Katolička s Grkokatoličkom, Evangelička, Islamska i Židovska (Radić, 1995., 21). Ostale vjerske zajednice bile su zabranjene i njihovi pripadnici progonjeni.

Usvojene i priznate vjeroispovijedi imale su jednak status pred zakonom i mogle su svoje obrede ispovijedati javno. Unutarnje vjerske poslove samostalno su uređivale, a zakladama i fondovima upravljale u granicama zakona. Dopušteno je održavanje veza s vjerskim poglavarstvima $u$ inozemstvu, uz ograničenje da se ta materija regulira zakonom. Odobrena proračunska sredstva raspoređivala su se prema broju vjernika i dokazanoj potrebi. Vjerskim predstavnicima bilo je zabranjeno da duhovnu vlast preko bogomolja, napisa vjerskoga karaktera ili na neki drugi način zlouporabe u partijske svrhe.

Spori rad Sabora Kraljevine na donošenju planiranoga vjerskog zakonodavstva bio je posljedica ukupne nestabilnosti i političkih borba koje su obilježile prve godine postojanja nove države (Pantić, 2006.). Situacija se osjetno promijeni- 
DRUŠ. ISTRAŽ. ZAGREB GOD. 20 (2011) BR. 2 (112),

STR. 517-539

NOVAKOVIĆ, D. POLOŽAJ CRKAVA... la nakon državnog udara u siječnju 1929. godine. Proklamirajući načelo o državnom i nacionalnom jedinstvu, režim je nastojao za ostvarenje tih ciljeva osigurati podršku vjerskih zajednica. Tijekom 1929. i 1930. godine doneseni su zakoni o Srpskoj pravoslavnoj Crkvi, Vjerskoj zajednici Židova, Islamskoj vjerskoj zajednici i Evangeličko-kršćanskim crkvama te Reformiranoj kršćanskoj Crkvi. ${ }^{10}$ Nespremnost vladajuće elite i otpor Srpske pravoslavne crkve spriječili su ratifikaciju već potpisanoga Konkordata, kojim je detaljno bio uređen položaj Katoličke crkve u Kraljevini (Mužić, 1978.).

\section{SOCIJALISTIČKA JUGOSLAVIJA}

Neposredno nakon oslobođenja zemlje, nova vlast nastojala je izgraditi pravni sustav koji bi učvrstio i stabilizirao rezultate postignute u ratu. Primarni zadatak bio je pravnim propisima spriječiti svaku mogućnost povratka na stari društveni sustav i onemogućiti aktivnosti koje bi mogle dovesti do međunacionalnih trvenja i vjerske mržnje. Polazeći od tih ciljeva, Predsjedništvo AVNOJ-a donijelo je 25. svibnja 1945. godine Zakon o zabrani izazivanja nacionalne, rasne i vjerske mržnje i razdora (Nešović i Petranović, 1983., 696). Drugi propis, koji se ticao položaja i djelovanja vjerskih zajednica, a koji je donesen prije novog Ustava, bila je Uredba Vlade DFR Jugoslavije o osnivanju Savezne i republičkih komisija za vjerska pitanja (Lazić, 1970., 57).

Za trajanja Socijalističke Jugoslavije donesena su tri savezna ustava: 1946., 1963. i 1974. godine. Budući da su odredbe koje se odnose na položaj religije i djelovanje vjerskih zajednica, osim nekih terminoloških objašnjenja i usklađivanja $s$ praksom, u osnovi dosta slične, upozorit će se na temeljna opredjeljenja umjesto pojedinačnih objašnjenja za svaki ustav. Svi ustavi jamčili su slobodu savjesti i vjeroispovijedi kao bitnu pretpostavku ostvarivanja ukupnih ljudskih sloboda u socijalističkoj zajednici. Vjera je tretirana kao privatna stvar svakoga pojedinca, koja za državu više nije od posebne važnosti. Dosljedno je primijenjeno načelo o odvojenosti vjerskih zajednica od države, a isti stav zauzet je i za odnos škole i Crkve. Ustavi proklamiraju potpunu slobodu vjerskih zajednica u obavljanju poslova i obreda. Vjerskim zajednicama dopušteno je osnivanje škola za odgoj svećenika i vjerskih službenika. Ustav iz 1946. godine propisuje slobodu vjerskih škola, ali utvrđuje i opći nadzor države. Zbog nejasnoće ove odredbe i stavova što su ih zastupali predstavnici nekih vjerskih zajednica da je svaka škola osnovana od mjerodavnoga crkvenoga tijela vjerska, u Ustavu iz 1974. godine precizno je navedena mogućnost osnivanja samo škola za odgoj svećenika. Ustavi su omogućavali vjerskim zajednicama pravo stjecanja vlasništva nad nekretninama. Predviđena je materijalna po- 
DRUŠ. ISTRAŽ. ZAGREB GOD. 20 (2011), BR. 2 (112)

STR. 517-539

NOVAKOVIĆ, D. POLOŽAJ CRKAVA. moć vjerskim zajednicama, ali ustavi ne preciziraju uvjete nužne za realizaciju pomoći niti utvrđuju obvezu države da je redovito pruža. Ustavi sadrže na različit način formuliranu odredbu o protuustavnoj zloporabi vjere u političke svrhe. Pojam "zloporaba vjere u političke svrhe" tumačio se na različite načine, ali je prihvaćen stav o obavljanju vjerskih poslova i obreda suprotno odredbama ustava i interesima zemlje. Praksa nije do kraja razjasnila podrazumijeva li zloporaba vjere u političke svrhe i njezino stavljanje $u$ funkciju sustava, ali je bilo visoko cijenjeno svako angažiranje svećenika kao građana na ostvarivanju prihvaćene politike i podržavano njihovo sudjelovanje u akcijama od širega društvenog značaja. ${ }^{11}$

Ustavne i zakonske odredbe vrijedile su i za Katoličku cr$\mathrm{kvu}$, ali su specifičnosti organizacije i poštovanje povijesne tradicije pridonijeli tomu da socijalistička Jugoslavija s Vatikanom 25. lipnja 1965. godine potpiše poseban Protokol kojim su uređeni odnosi dvaju subjekata međunarodnoga prava i precizirana pozicija Crkve u novoj državi. ${ }^{12}$

Odredbe o vjerskim slobodama i položaju religije te djelovanju vjerskih zajednica sadržavali su i ustavi svih republika, a od 1974. godine i pokrajina. Budući da se to područje temeljilo na jedinstvenoj ideološkoj osnovi utjelovljenoj u vladavini Saveza komunista, gotovo sva rješenja u tim ustavima identična su odredbama saveznih ustava, tako da nema potrebe za detaljnijim obrazlaganjem. ${ }^{13}$

\section{RAZDOBLJE DO PONOVNOGA USPOSTAVLJANJA DRŽAVNOSTI}

Političke potrebe tadašnjega rukovodstva i sve očiglednija kriza zajedničke države izravno su pridonijele donošenju novog Ustava Republike Srbije 28. rujna 1990. godine. Položaju vjerskih zajednica i vjerskim slobodama posvećen je 41. članak i njime nije učinjen odlučniji iskorak $u$ odnosu na ustave socijalističke Jugoslavije. Građanima se jamči sloboda vjeroispovijedi, u koju su uključeni sloboda vjerovanja, ispovijedanja vjere i obavljanje vjerskih obreda. Vjerske su zajednice odvojene od države i slobodne u obavljanju vjerskih poslova i obreda, uz zajamčeno pravo da osnivaju škole i dobrotvorne organizacije. Zadržana je i ranija odredba o mogućnosti države da materijalno pomaže vjerske zajednice (Ustav Republike Srbije, 1990.).

Ustav Savezne Republike Jugoslavije od 27. travnja 1992. godine ovoj problematici posvećuje 18., 20., 43. i 50. članak, što upućuje na namjeru ustavotvorca da to područje prilagodi međunarodnim standardima, ali i da zadrži neka rješenja iz ranijega ideološkog razdoblja. Umjesto termina "vjerske zajednice" promovira se novi "crkve" i propisuje odvojenost od države te potpuna ravnopravnost i sloboda u obavljanju vjer- 
DRUŠ. ISTRAŽ. ZAGREB GOD. 20 (2011) BR. 2 (1 12$)$,

STR. 517-539

NOVAKOVIĆ, D. POLOŽAJ CRKAVA... se vjera ravnopravno tretira s pripadnosti naciji, rasi, spolu, jeziku i drugom osobnom svojstvu. Jamči se sloboda vjerovanja, javnog i privatnog ispovijedanja vjere te obavljanja vjerskih obreda i pravo pojedinca da se ne izjašnjava o svojem vjerskom uvjerenju. Navedeni Ustav ponovno promovira načelo protuustavnosti i kažnjivosti svakog izazivanja i poticanja nacionalne, rasne, vjerske ili druge neravnopravnosti i mržnje (Ustav Savezne Republike Jugoslavije, 1992.).

Kompromisna i tekstom kratka "Ustavna povelja Državne zajednice Srbije i Crne Gore", usvojena 4. veljače 2003. godine, ne sadrži odredbe o slobodi vjeroispovijedi i o položaju vjerskih zajednica (Ustavna povelja Državne zajednice Srbija i Crna Gora, 2003.). Člankom 9. predviđeno je donošenje posebne "Povelje o ljudskim i manjinskim pravima i građanskim slobodama", koja je usvojena 28. veljače 2003. godine. Kompletna Povelja napravljena je prema modernim standardima, usklađena s gotovo svim međunarodnim dokumentima koji reguliraju tu oblast, i velik je iskorak njezinih tvoraca prema normama koje vrijede u Europskoj uniji. Slobodi misli, savjesti i vjeroispovijedi posvećen je 26. članak, a 27. vjerskim zajednicama. Budući da je dio o slobodi misli, savjesti i vjeroispovijedi iz Povelje bio polazna osnova za uređenje te materije u najnovijem Ustavu Srbije, smatramo da nema potrebe $\mathrm{u}$ pozoravati na neke manje razlike. Povelja određuje ravnopravnost i odvojenost vjerskih zajednica od države, slobodu da samostalno uređuju svoj unutarnji ustroj, vjerske poslove i obrede, kao i pravo da osnivaju škole i dobrotvorne organizacije u skladu sa zakonom (Povelja o ljudskim i manjinskim pravima i građanskim slobodama, 2003.).

\section{NAJNOVIJI USTAV SRBIJE}

Novi Ustav Republike Srbije, proglašen 8. studenog 2006. godine, u člancima 11., 43. i 44. uređuje položaj Crkava i vjerskih zajednica te slobodu vjeroispovijedi. Članak 11. sa tri stavka nalazi se u prvom dijelu "Načela ustava" i njegov naziv glasi "Svetovnost države". Stavak 1. navedenoga članka utvrđuje svjetovnost Republike Srbije, stavak 2. istoga članka odvojenost Crkava i vjerskih zajednica od države, a stavak 3. istoga članka nemogućnost ustanovljavanja neke religije kao državne ili obvezne. Međunarodni standardi ne propisuju poseban model odnosa između države i vjere, ali sve najvažnije međunarodne konvencije koje uređuju ovo područje zabranjuju diskriminaciju onih koji ne pripadaju službenoj religiji i priznatim vjerama (Razumevanje ljudskih prava, 2005., 163-174). Budući da u Europi prevladava odvojenost države od Crkve kao najprihvatljiviji okvir za ostvarivanje ravnopravnosti, Sr- 
DRUŠ. ISTRAŽ. ZAGREB GOD. 20 (2011), BR. 2 (112)

STR. 517-539

NOVAKOVIĆ, D. POLOŽAJ CRKAYA. bija je navedenim člankom svoju ustavnu praksu uskladila s europskim standardima.

Ćlanci 43. i 44. nalaze se u drugom dijelu Ustava "Ljudska i manjinska prava i slobode". Prvi ima naziv "Sloboda misli, savesti i veroispovesti" i sastoji se od pet stavaka. Stavak 1. članka 43. jamči slobodu misli, savjesti, uvjerenja i vjeroispovijedi, pravo da se ostane pri svom uvjerenju ili vjeroispovijedi ili da se oni promijene prema vlastitu izboru, dok stavak 2. istoga članka objašnjava da nitko nije dužan izjašnjavati se o svojim vjerskim i drugim uvjerenjima. Usporedbom prvih dvaju stavaka kao najvažnija za ostvarivanje prava na slobodu vjeroispovijedi može se konstatirati potpuna usklađenost sa člankom 18. Univerzalne deklaracije o pravima čovjeka, člankom 9. točka 1. Europske konvencije o zaštiti ljudskih prava i osnovnih sloboda, Zaključnim dokumentom Bečkoga sastanka OEBS-a od 15. siječnja 1989. i Pariškom poveljom za novu Europu od 21. studenog 1990. godine.

Zajamčivši slobodu misli, savjesti i vjeroispovijedi, ustavotvorac je u stavku 3. istoga članka odredbom da je svatko slobodan izražavati svoju vjeru ili uvjerenje vjeroispovijedanja, obavljanjem vjerskih obreda, pohađanjem vjerske službe ili nastave, pojedinačno ili u zajednici s drugima, kao i privatno ili javno iznositi svoja uvjerenja, praktički promovirao pet precizno navedenih načina izražavanja vjere ili uvjerenja. Ako se provedu odgovarajuće usporedbe s međunarodnim pravom, ustanovit ćemo zamjetnu podudarnost s člankom 6. Deklaracije o ukidanju svih oblika netolerancije i diskriminacije temeljene na vjeri ili uvjerenju.

Posebno je važan stavak 4. istoga članka, u kojemu je istaknuto da se sloboda izražavanja vjere ili uvjerenja može ograničiti zakonom samo ako je to nužno $\mathrm{u}$ demokratskom društvu, radi zaštite života i zdravlja ljudi, morala demokratskoga društva, sloboda i prava zajamčenih Ustavom, javne sigurnosti i javnoga reda ili radi sprečavanja izazivanja ili poticanja vjerske, nacionalne ili rasne mržnje. Komparacija navedenih rješenja potvrđuje da se ustavotvorac rukovodio gotovo identičnim člankom 9. točka 2. Europske konvencije o ljudskim pravima i osnovnim slobodama i člankom 18. točka 3. Međunarodnog pakta o građanskim i političkim slobodama (Murdok, 2008.).

Stavak 5. istoga članka jamči pravo roditelja i zakonskih staratelja da svojoj djeci osiguraju vjersko i moralno obrazovanje u skladu sa svojim uvjerenjima, čime je Ustav izravno prihvatio obvezu propisanu državama člankom 18. točka 4 . Međunarodnoga pakta o građanskim i političkim slobodama i člankom 13. Međunarodnoga pakta o ekonomskim, socijalnim i kulturnim pravima (Krivokapić, 1., 2004.). 
DRUŠ. ISTRAŽ. ZAGREB GOD. 20 (2011) BR. 2 (112)

STR. 517-539

NOVAKOVIĆ, D. POLOŽAJ CRKAVA...

\section{ZAKLJUČAK}

Članak 44. Ustava Republike Srbije nosi naziv "Crkve i verske zajednice". Stavak 1 . navedenoga članka utvrđuje ravnopravnost Crkava i vjerskih zajednica te odvojenost od države. Prema stavku 2. istoga članka, Crkve i vjerske zajednice ravnopravne su i slobodne samostalno uređivati svoj unutarnji ustroj, vjerske poslove, vjerske obrede, osnivati vjerske škole, socijalne i dobrotvorne ustanove i njima upravljati u skladu sa zakonom. Stavkom 3. istoga članka određeno je da Ustavni sud može zabraniti vjersku zajednicu samo ako njezino djelovanje ugrožava pravo na život, pravo na psihičko i tjelesno zdravlje, pravo djece, pravo na osobni i obiteljski integritet, pravo na imovinu, javnu sigurnost i javni red ili ako izaziva i potiče vjersku, nacionalnu ili rasnu nesnošljivost.

Analizom stavka 1. članka 44 . uočava se velika sličnost s rješenjima iz članka 11. stavak 2. Ustava, uz dodanu riječ "ravnopravne". Polazeći od članka 6. Deklaracije o ukidanju svih oblika netolerancije i diskriminacije na temelju vjere i uvjerenja i podtočke 16.4. Zaključnog dokumenta Bečkog sastanka OEBS-a od 15. siječnja 1989. godine, u kojima se navodi širi spektar kolektivnih prava Crkava i vjerskih zajednica, u stavku 2. istoga članka taksativno je nabrojeno samo šest jasno preciziranih prava. Prakticiranje navedenih sloboda provodi se u skladu sa zakonom, što se slaže s točkom 17 . Zaključnoga dokumenta Bečkoga sastanka OEBS-a, koji daje pravo državama sudionicama da precizno navedena šira prava u svezi sa slobodom vjeroispovijedi ili konfesija ograniče samo zakonom i u skladu s njihovim međunarodnim obvezama (Krivokapić, 2., 2004.).

Precizirajući uvjete moguće zabrane rada, Ustav u stavku 3. istoga članka izostavlja Crkve i rabi samo naziv "vjerske zajednice". Takva formulacija može upućivati na zaključak da Ustavni sud ne može zabraniti rad Crkava, ali da to pravo ima u svim slučajevima kada su u pitanju vjerske organizacije koje u nazivu sadrže ime "zajednica". Budući da vjerskim zajednicama pripadaju i neke sa statusom tradicionalnih, a Crkvama i Kršćanska adventistička, s pravom se može zaključiti da je u pitanju nedosljednost $\mathrm{u}$ uporabi termina, a ne namjera neopravdanoga stvaranja razlika između Crkava i vjerskih zajednica. Formulirajući u istom stavku uvjete pod kojim Ustavni sud može zabraniti vjersku zajednicu, ustavotvorac je sa zamjetnom dosljednosti primijenio odredbe članka 43. stavak 4., koji se odnose na predviđena ograničenja izražavanja vjere ili uvjerenja (Ustav Republike Srbije, 2006.).

U stotinu sedamdeset i šest godina Srbija i države u čiji je sastav bila uključena donijele su više ustava, kojima je osnovna karakteristika dominacija utjecaja velikih sila u prvoj polovici XIX. stoljeća, poštovanje odnosa dominantnih snaga na unu- 
DRUŠ. ISTRAŽ. ZAGREB GOD. 20 (2011), BR. $2(112)$

STR. 517-539

NOVAKOVIĆ, D. POLOŽAJ CRKAYA. tarnjem planu do Drugoga svjetskog rata, poštovanje principa vladajuće ideologije u socijalističkoj Jugoslaviji, eksperimentiranje i traženje optimalnih rješenja od 1991. do 2003. godine i primjena međunarodnih dokumenata kojima se uređuje položaj Crkava i vjerskih zajednica i ostvarivanje vjerskih sloboda na kraju razdoblja.

Hatišerif kao prvi ustavni akt, donesen uz pomoć velikih sila, jamčio je samo elementarno pravo na vjeroispovijed, slobodu bogoslužja i samostalni izbor najvišega crkvenog klera. Kratkotrajni "Sretenjski ustav" bio je velik iskorak i ugrađene odredbe služile su kao orijentir najnaprednijem dijelu srbijanske političke elite u nastojanjima da izradi ustavni tekst koji će poštovati stvarnost i omogućiti stalni napredak države. Postignuto "Sretenjskim", u velikoj je mjeri eliminirano tzv. "Turskim ustavom", koji na institucionalan način ponovno uspostavlja političko pokroviteljstvo Turske nad Srbijom, a Srpsku crkvu vraća pod okrilje "Vaseljenske patrijaršije". Proistekao iz dvostruke smjene dinastija i napora srbijanskoga društva da se oslobodi od orijentalnoga naslijeđa i okrene prema Europi, sljedeći Ustav utvrđuje vladajući status istočne Pravoslavne crkve i jamči slobodu priznatih vjera. Napuštajući tradicionalno rusofilstvo i opredjeljujući se za savezništvo s Austrijom, Srbija je 1888. godine usvojila moderni i napredni Ustav, koji slobodu savjesti određuje kao neograničenu. Donesen u dramatičnim okolnostima nakon još jedne dinastičke smjene i proizašao iz namjere novoga vladara da učvrsti temelje sve snažnije države, Ustav iz 1903. godine preuzeo je u cijelosti sva rješenja iz prethodnoga Ustava koja se odnose na Srpsku crkvu i ostale priznate vjeroispovijedi.

Opterećena unutarnjim proturječjima, Kraljevina Jugoslavija nije u donesenim ustavima uspjela provesti konzistentnu vjersku politiku, neprekidno lutajući između realnosti koja je nametala prihvaćanje europskih standarda o odvojenosti vjerskih zajednica od države i nespremnosti na odricanje od državnopravne tradicije Srbije i Crne Gore, u kojima je Pravoslavna crkva imala status državne i zaštićene. Zakoni doneseni nakon državnog udara 1929. godine potvrdili su namjeru države da izravno utječe na sve važne procese u vjerskim zajednicama, uključujući i izbor vrhovnih poglavara, a neuspjeh sklapanja konkordata pokazao je i nespremnost vladajuće političke elite da Katoličkoj crkvi jamči prava dana drugima i nesposobnost da na trajan način uredi složeno vjersko pitanje.

Ustavi socijalističke Jugoslavije rađeni su prema sovjetskom modelu i s ciljem da dosljedno realiziraju restriktivnu i u osnovi neprijateljsku politiku vladajuće partije prema vjerskim zajednicama kao najvećem ideološkom protivniku. Ako se promatraju neovisno o tadašnjem društvenom kontekstu, 
DRUŠ. ISTRAŽ. ZAGREB GOD. 20 (2011) BR. 2 (112)

STR. 517-539

NOVAKOVIĆ, D. POLOŽAJ CRKAVA... odredbe o slobodi savjesti i vjeroispovijedi, odvojenosti vjerskih zajednica od države, slobodi vjerskih obreda, mogućnosti osnivanja vjerskih škola i stjecanju nekretnina mogu djelovati moderno i u skladu s demokratskim standardima. Formalni karakter navedenih ustavnih sloboda postaje jasniji usporedbom s faktičkim položajem vjerskih zajednica u društvu i činjenicom da su nizom zakona donesenim između 1946. i 1958. godine lišene materijalne osnove i prepuštene arbitrarnosti tijela vlasti.

Nastojeći provesti distanciranje od još uvijek zajedničke države u kojoj se većina republika opredijelila za višestranački sustav i tržišno gospodarstvo, ali i da zadrže vladavinu jednopartijskoga sustava, Ustav Srbije iz 1990. godine ne uspijeva napraviti veći iskorak na tom području i ostaje omeđen nastojanjima jedne već prevladane ideologije da očuva primat i ne dopusti konkurenciju. Ustavi dviju država proistekli iz zajedničke volje srbijanskoga i crnogorskoga naroda bitno se razlikuju, jer su prvi načinili ideološki istomišljenici u obje republike, dok je drugi s nazivom "Povelja" nastao nakon demokratskih promjena u Srbiji i uz posredovanje međunarodne zajednice kao kompromisno i vremenski oročeno rješenje partnera čije su se političke vizije o europskoj budućnosti podudarale, ali i bitno razlikovale kada je u pitanju nastavak zajedničkoga života.

Predstavljena povijesna vertikala završena je Srbijom kao neovisnom demokratskom državom koja nastoji svoju budućnost graditi oslobađanjem od traumatičnih iskustava iz bliske prošlosti i uz oslonac na najbolje tradicije iz vlastite državnosti. Nastojanja da složena pitanja položaja Crkava i vjerskih zajednica i slobode vjeroispovijedi u novom Ustavu uskladi s najvažnijim međunarodnim dokumentima pokazuju spremnost Srbije da nadoknadi zaostatak u odnosu na okruženje i odlučno pristupi provedbi politike kojoj je cilj ubrzano približavanje Europskoj uniji.

\section{BILJEŠKE}

1 Potpisani sporazum utvrđuje da će ubuduće metropolite i episkope birati knez i narod između najdostojnijih kandidata u zemlji. Beogradski metropolit imat će u tituli i određenje "cijele Srbije" iz čega proizlazi obveza ostalih episkopa na pokoravanje i priznavanje prvenstva. Kada dobije obavijest o kandidatu za metropolita, "vaseljenski patrijarh" će bez odgađanja dati blagoslov i naredbu za "rukopoloženje" u Srbiji (Anastasijević, 1910.).

2 Međunarodno priznanje neovisnosti Srbije značilo je ispunjenje kanonskih uvjeta za pregovore s "Vaseljenskom patrijaršijom" o punoj autokefalnosti Srpske crkve u državnim granicama. Ministar vanjskih poslova organizirao je i vodio kompletni postupak, a zastupnik u Carigradu pregovarao s "vaseljenskim patrijarhom". Pri- 
DRUŠ. ISTRAŽ. ZAGREB GOD. 20 (2011), BR. $2(112)$

STR. 517-539

NOVAKOVIĆ, D.: POLOŽAJ CRKAVA. hvaćajući dogovoreno, Sveti arhijerejski sinod "Vaseljenske patrijaršije" izdao je 20. listopada 1879. godine tomos o potpunoj samostalnosti Srpske pravoslavne crkve u Kneževini Srbiji (Mitropolit Mihailo, 1895., 7-9.).

3 Tijekom svoje vladavine, kralj Aleksandar provodio je određene ustavne promjene $u$ tadašnjoj Srbiji. Proklamacijom od 9. svibnja 1894. godine ukinuo je Ustav iz 1888. i vratio na snagu namjesnički iz 1868. godine. Nastojeći ublažiti unutarnje nezadovoljstvo, 6. travnja 1901. godine "darovao" je novi Ustav. Položaj Srpske crkve i ostalih priznatih vjeroispovijedi novim Ustavom nije bitnije promijenjen, Ustav Kraljevine Srbije - 1901.

${ }^{4}$ Pravni položaj vjerskih zajednica u zemljama koje su ušle u sastav Kraljevine SHS predstavljen je detaljno u sljedećim tekstovima: Slijepčević, 1966.; Veselinović, 1969. a, b, c; Durković Jakšić, 1969.; Episkop dalmatinski Stefan, 1969.; Ceranić, 1970.; Šehić, 1980.

${ }^{5}$ Navedeni Privremeni zakon inkorporiran je u Vidovdanski ustav u odjeljak drugi - Osnovna građanska prava i dužnosti iza članka 4., Ustav Kraljevine Srba, Hrvata i Slovenaca - Vidovdanski ustav, 1921.

6 Proglašenjem Kraljevine SHS, svih šest pokrajinskih crkava koje su okupljale srpski narod našle su se u teritorijalnom okviru nove države. Nakon uspješno provedenih pregovora sa Svetim arhijerejskim sinodom "Vaseljenske patrijaršije", prijestolonasljednik Aleksandar je posebnim ukazom od 17. lipnja 1920. godine proglasio jednu Autokefalnu ujedinjenu Srpsku pravoslavnu Crkvu Kraljevine SHS (Stranjaković, 1960.; Gardašević, 1969.).

7 Usvojene i priznate vjerske zajednice vodile su uime države matice rođenih, vjenčanih i umrlih, a bračne sporove presuđivali su crkveni sudovi. Za pripadnike Islamske vjerske zajednice, šerijatski sudovi rješavali su i imovinsko-pravne sporove.

8 Ustav Kraljevine Srba, Hrvata i Slovenaca - Vidovdanski ustav 1921. članak 12. stavak 3.; Ustav Kraljevine Jugoslavije 1931., članak 11. stavak 1. i 3.

9 Lazić, 1970.; Unković, 1978., 12; Grupa autora, 1972., 5; Bjelajac, 2001. 33-41.

10 Zakon o Srpskoj pravoslavnoj crkvi, 1929.; Zakon o verskoj zajednici Jevreja u Kraljevini Jugoslaviji, 1929.; Zakon o Islamskoj verskoj zajednici u Kraljevini Jugoslaviji, 1930.; Zakon o Evangeličko-hrišćanskim i o Reformovanoj hrišćanskoj crkvi u Kraljevini Jugoslaviji, 1930.

11 Vidjeti: Ustav Federativne Narodne Republike Jugoslavije, 1948., članak 26; Ustav Socijalističke Federativne Republike Jugoslavije, 1963., članak 41; Ustav Socijalističke Federativne Republike Jugoslavije, 1974., članak 174.

12 Odnosi između socijalističke Jugoslavije i Vatikana neposredno nakon rata nisu upućivali na mogućnost dramatičnih događaja do kojih je došlo nekoliko godina kasnije. Osiguravši međunarodnopravni kontinuitet, jugoslavenska Vlada regulirala je odnose is Vatikanom i uspostavila redovite diplomatske odnose. Imenovanje osuđenoga zagrebačkog nadbiskupa Alojzija Stepinca kardinalom jugoslavenske su vlasti procijenile kao smišljenu provokaciju i u znak 
DRUŠ. ISTRAŽ. ZAGREB GOD. 20 (2011), BR. 2 (112),

STR. 517-539

NOVAKOVIĆ, D. POLOŽAJ CRKAVA... neslaganja s tom odlukom, notom od 17. prosinca 1952. godine, zatražile da otpravnik poslova, monsinjor Silvio Oddi, napusti Beograd. Elastičnija politika Vatikana prema Jugoslaviji nakon izbora pape Ivana XXIII., dovela je do više posrednih kontakata, ali su službeni razgovori otežavani zbog čvrstoga stajališta Svete Stolice da pitanje normalizacije odnosa prva treba pokrenuti Jugoslavija, jer su na njezin zahtjev i prekinuti. Nakon dugih pregovora i usklađivanja svih spornih pitanja, formulirani tekst, koji je u konačnoj verziji dobio naziv Protokol, potpisali su u Beogradu uime Vlade SFRJ Milutin Morača, a uime Vatikana Agostino Casaroli. Vidjeti: Unković, 1978.; Cvrlje, 1975.; Cvrlje, 1980.

13 Vidjeti Ustav SR BiH, 1974., članak 184; Ustav SR Crne Gore, 1974. članak 200; Ustav SR Hrvatske, 1974., članak 258; Ustav SR Makedonije, 1974., članak 225; Ustav SR Slovenije, 1974., članak 229; Ustav SR Srbije, 1974., članak 197; Ustav SAP Kosova, 1974., članak 190 i Ustav SAP Vojvodine, 1974., članak 197.

\section{LITERATURA}

Anastasijević, N. (1910.), Pismo Carigradskog Patrijarha Konstantija o proglašenju aftokefalne srpske crkve od 1832. godine meseca januara, Spomenik Srpske kraljevske akademije, XLIX, drugi razred, 42: 13-15, Beograd: Srpska kraljevska akademija.

Bjelajac, B. (2001.), O istoričnosti malih protestantskih verskih zajednica u Srbiji. U: B. Bjelajac i D. Vidović (ur.), Udar na verske slobode (str. 33-38). Beograd: Alfa i Omega.

Ceranić, I. (1970.), Konfesionalne zajednice u Jugoslaviji. U: Z. Frid (ur.), Vjerske zajednice u Jugoslaviji (str. 7-44), Zagreb: Binoza.

Cvrlje, V. (1975.), Politika dijaloga pape Ivana XXIII. Naše teme, 19 (12): 1887-1909.

Cvrlje, V. (1980), Vatikan u suvremenom svijetu, Zagreb: Školska knjiga. Ćorović, V. (1989.), Istorija Srba, treći deo, Beograd: BIGZ.

Durković Jakšić, Lj. (1969.), Srpska pravoslavna crkva 1219-1969, spomenica o 750-godišnjici autokefalnosti, Udeo cetinjske mitropolije u borbi za uspostavljanje redovnog stanja u Srpskoj pravoslavnoj crkvi (str. 241-270). Beograd: Sveti arhijerejski sinod SPC.

Ekmečić, M. (1989.), Stvaranje Jugoslavije 1790-1918, 1, Beograd: Prosveta.

Episkop dalmatinski Stefan (1969.), Srpska pravoslavna crkva 1219-1969, spomenica o 750-godišnjici autokefalnosti, Srpska crkva u Dalmaciji i Boki Kotorskoj (str. 271-290). Beograd: Sveti arhijerejski sinod SPC.

Gardašević, B. (1969.), Srpska pravoslavna crkva 1920-1970, spomenica o 50-godišnjici vaspostavljanja Srpske patrijaršije, Organizaciono ustrojstvo i zakonodavstvo pravoslavne crkve između dva svetska rata (str. 37-64). Beograd: Sveti arhijerejski sinod SPC.

Gavrilović, M. (1912.), Miloš Obrenović, treća knjiga, Beograd: Štamparija Davidović.

Grupa autora (1972.), Društveno-politički položaj i pravni režim verskih zajednica u Jugoslaviji, Beograd: Institut za savremenu istoriju. 
DRUŠ. ISTRAŽ. ZAGREB GOD. 20 (2011), BR. 2 (112)

STR. 517-539

NOVAKOVIĆ, D.: POLOŽAJ CRKAVA.
Janković, D. (1985.), Predistorija Sretenjskog ustava i neke napomene u vezi s njim, 150 godina od donošenja Sretenjskog ustava (str. 9-20). Kragujevac: Univerzitet u Kragujevcu.

Jovanović, S. (1905.), Naše ustavno pitanje u XIX veku, Srpski književni glasnik, knjiga XIV: 589-590, Beograd.

Krivokapić, B. (2004.), Zaštita manjina u međunarodnom i uporednom pravu 1 i 2, Beograd: Institut za uporedno pravo.

Lazić, I. (1970.), Pravni i činjenični položaj vjerskih zajednica u Jugoslaviji, Vjerske zajednice u Jugoslaviji (str. 45-77). Zagreb: Binoza.

Mitropolit Mihailo (1895.), Pravoslavna Srpska crkva u Kraljevini Srbiji, Joakim po milosti Božijoj Arhijepiskop Carigrada, Novog Rima i Vaseljenski patrijarh, odnosno akt broj 4163 kojim je proglašena kanonska samostalnost Srpske crkve (str. 6-11). Beograd: Kraljevska srpska državna štamparija.

Murdok, Dž. (2008.), Sloboda misli, savesti i veroispovesti, Beograd: Savet Evrope.

Mužić, I. (1978.), Katolička crkva u Kraljevini Jugoslaviji, Split: Crkva u svijetu.

Nešović, S. i Petranović, B. (1983.), AVNOJ i revolucija, Beograd: Nolit. Novaković, D. (2002.), Konkordati Knjaževine Crne Gore i Kraljevine Srbije sklopljeni sa Vatikanom 1886. i 1914. godine. Arhiv za pravne i društvene nauke, Beograd, (4): 533-558.

Novaković, D. (2003.), Verske zajednice na razmeđu vekova, Beograd: Institut za političke studije.

Pantić, D. (2006.), Srpska pravoslavna crkva u Kraljevini Jugoslaviji 1929-1941, Istočno Sarajevo: Univerzitet u Istočnom Sarajevu, Pravni fakultet.

Povelja o ljudskim i manjinskim pravima i građanskim slobodama (2003.), Službeni list SCG, 6/2003, Beograd.

Radić, R. (1995.), Verom protiv vere, Beograd: Institut za noviju istoriju. Razumevanje ljudskih prava (2005.), urednik W. Benedek, Beograd: Beogradski centar za ljudska prava.

Slijepčević, Đ. (1966.), Istorija Srpske pravoslavne crkve, druga knjiga, Minhen: Iskra.

Stefanović, J. (1953.), Odnosi između crkve i države, Zagreb: Matica hrvatska.

Stranjaković, D. (1960.), Ujedinjenje Srpske pravoslavne crkve i obnova Pećke Patrijaršije, Glasnik, službeni listi SPC, Beograd, (4): 140-155.

Šehić, N. (1980.), Autonomni pokret muslimana za vrijeme Austrougarske uprave u Bosni i Hercegovini, Sarajevo: Svjetlost.

Troicki, S. (1935.), Verska politika Kralja Ujedinitelja. Letopis matice srpske, 343 (1): 1-18.

Unković, V. (1978.), Vjerske zajednice u uvjetima nastanka i razvoja nove Jugoslavije, Beograd, neobjavljena doktorska disertacija odbranjena na Pravnom fakultetu.

Ustav Federativne Narodne Republike Jugoslavije (1948.), Beograd: Službeni list FNRJ. 
DRUŠ. ISTRAŽ. ZAGREB GOD. 20 (2011), BR. 2 (112),

STR. 517-539

NOVAKOVIĆ, D. POLOŽAJ CRKAVA...
Ustav Knjažestva Serbije - 1835. (1988.), Ustavi i vlade Kneževine Srbije, Kraljevine Srbije, Kraljevine SHS i Kraljevine Jugoslavije (1835-1941), (str. 27-42). Beograd: Nova knjiga.

Ustav Knjažestva Serbije tj. sultanski hatišerif - 1838. (1988.), Ustavi i vlade Kneževine Srbije, Kraljevine Srbije, Kraljevine SHS i Kraljevine Jugoslavije (1835-1941), (str. 53-60). Beograd: Nova knjiga.

Ustav Kraljevine Jugoslavije, Službene novine Kraljevine Jugoslavije, 200/1931., Beograd.

Ustav Kraljevine SHS - Vidovdanski ustav, Službene novine Kraljevine SHS, 142a/1921., Beograd.

Ustav Kraljevine Srbije - 1901. (1988.), Ustavi i vlade Kneževine Srbije, Kraljevine Srbije, Kraljevine SHS i Kraljevine Jugoslavije (1835-1941), (str. 107-133). Beograd: Nova knjiga.

Ustav od 1869. godine (1988.), tekst uz Ustav za Knjažestvo Srbiju 1869, Ustavi i vlade Kneževine Srbije, Kraljevine Srbije, Kraljevine SHS $i$ Kraljevine Jugoslavije (1835-1941), (str. 71-72). Beograd: Nova knjiga.

Ustavna povelja Državne zajednice SCG, Službeni list SCG, 1/2003., Beograd.

Ustav Republike Srbije, Službeni glasnik RS, broj 1/90., Beograd.

Ustav Republike Srbije, Službeni glasnik RS, 1/2006., Beograd.

Ustav SAP Kosova, Službeni list SAP Kosovo, 4/74., Priština.

Ustav SAP Vojvodine, Službeni list SAP Vojvodine, 4/74., Novi Sad.

Ustav Socijalističke Federativne Republike Jugoslavije (1974.), Beograd: Službeni list SFRJ.

Ustav Socijalističke Federativne Republike Jugoslavije (1963.), Beograd: Službeni list SFRJ.

Ustav SR BiH, Službeni list SR BiH, 4/74., Sarajevo.

Ustav SR Crne Gore, Službeni list SR Crne Gore, 5/74., Titograd.

Ustav SR Hrvatske, Službene novine SR Hrvatske, 8/74., Zagreb.

Ustav SR Makedonije, Služben vesnik na SRM, 7/74., Skopje.

Ustav SR Srbije, Službeni glasnik SRS, 8/74., Beograd.

Ustava SR Slovenije, Uradni list SRS, 6/74., Ljubljana.

Ustav Savezne Republike Jugoslavije, Službeni list SRJ, 1/1992., Beograd. Ustav za Knjažestvo Srbiju - 1869. (1988.), Ustavi i vlade Kneževine Srbije, Kraljevine Srbije, Kraljevine SHS i Kraljevine Jugoslavije (1835.-1941.), (str. 73-88). Beograd: Nova knjiga.

Ustav za Kraljevinu Srbiju - 1888. (1988.), Ustavi i vlade Kneževine Srbije, Kraljevine Srbije, Kraljevine SHS i Kraljevine Jugoslavije (1835.-1941.), (str. 107-133). Beograd: Nova knjiga.

Ustav za Kraljevinu Srbiju - 1903. (1988.), Ustavi i vlade Kneževine Srbije, Kraljevine Srbije, Kraljevine SHS i Kraljevine Jugoslavije (1835.-1941.), (str. 171-187). Beograd: Nova knjiga.

Veselinović, R. (1966.), Istorija Srpske pravoslavne crkve sa narodnom istorijom, knjiga dva (1766-1945), Beograd: Sveti arhijerejski sinod SPC.

Veselinović, R. (1969.a), Srpska pravoslavna crkva 1219-1969, spomenica o 750-godišnjici autokefalnosti, Pregled istorije crkve u Staroj Srbiji i Make- 
DRUŠ. ISTRAŽ. ZAGREB GOD. 20 (2011), BR. 2 (112)

STR. 517-539

NOVAKOVIĆ, D.: POLOŽAJ CRKAYA.

doniji od 1766. do 1919. godine (str. 331-336). Beograd: Sveti arhijerejski sinod SPC.

Veselinović, R. (1969.b), Srpska pravoslavna crkva 1219-1969, spomenica o 750-godišnjici autokefalnosti, Pregled istorije karlovačke mitropolije od 1695. do 1919. godine (str. 221-240). Beograd: Sveti arhijerejski sinod SPC.

Veselinović, R. (1969.c), Srpska pravoslavna crkva 1219-1969, spomenica o 750-godišnjici autokefalnosti, Srpska pravoslavna crkva u Bosni i Hercegovini (str. 319-330), Beograd: Sveti arhijerejski sinod SPC.

Wagner, V. (1933.), Povijest Katoličke crkve u Srbiji u 19. vijeku. Bogoslovska smotra, XXI (IV): 297-307.

Zakon o evangeličko-hrišćanskim i o reformovanoj hrišćanskoj crkvi u Kraljevini Jugoslaviji, Službene novine Kraljevine Jugoslavije, 1930., 17. april, Beograd.

Zakon o Islamskoj verskoj zajednici u Kraljevini Jugoslaviji, Službene novine Kraljevine Jugoslavije, 99/1930., Beograd.

Zakon o Srpskoj pravoslavnoj crkvi, Službene novine Kraljevine Jugoslavije, 269/1929., Beograd.

Zakon o verskoj zajednici Jevreja u Kraljevini Jugoslaviji, Službene novine Kraljevine Jugoslavije, 301/1929., Beograd.

\section{Position of Churches and Religious Communities and Exercise of Freedom of Worship within Serbian Constitutions}

\author{
Dragan NOVAKOVIĆ \\ Ministry of Religious Affairs of the Republic of Serbia, Belgrade
}

The paper concerned sets out the provisions of various Serbian Constitutions, which have been enacted in order to regulate the position of churches and religious communities, as well as the freedom of worship within the period of the contemporary Serbian statehood, also including the constitutional acts covering relatively long periods since Serbian involvement in different forms of the Yugoslav unions. Owing to the fact that a legal norm does not come to be out of nowhere and does not function based on its own principles, it was necessary to locate the entire process of promulgation of a constitution within some wider social and historical context providing better overview of the efforts exerted by the Serbian political and intellectual elite to find out the best possible form of state, which would be based on democratic principles and make it possible to attain continuous economic growth and cultural development. The analysis of original constitutional texts clearly demonstrates an uninterrupted progress in the matter of the freedom of worship, starting from the basic possibility of following up one's own religion, passing through the period of 
DRUŠ. ISTRAŽ. ZAGREB GOD. 20 (2011) BR. 2 (112)

STR. 517-539

NOVAKOVIĆ, D. POLOŽAJ CRKAVA... within the state as well as the right of other confessions to feel free and protected in exercising their activities, up to the harmonization of constitutional provisions relating to this rather sensitive field with the most important International Law documentation and the EU Acquis. The research work relating to the constitutional documentation and to the specific conditions in which the Serbian state has functioned either autonomously or in union with others, provide an outlook of one of the most significant periods of Serbian history, headed at the beginning by a despot, based on the oriental set of values, devoid of any institutional mechanisms to protect the basic human right to live, up to an independent state determined to build its future within the framework of the European Union, following in the tracks of the best democratic traditions.

Keywords: Serbia, Yugoslavia, constitutions, freedom of worship, churches, religious communities

\section{Die Position von Kirchen und Glaubensgemeinschaften und die Gewährung von Glaubensfreiheit in den Verfassungen Serbiens}

Dragan NOVAKOVIĆ

Ministerium für Glaubensangelegenheiten Serbiens, Belgrad

Der Autor präsentiert verfassungsmäßige Richtlinien, aufgrund deren in der modernen Staatsgeschichte Serbiens die Position von Kirchen und Glaubensgemeinschaften geregelt und Glaubensfreiheiten gewährt wurden; mit eingeschlossen sind die Verfassungsakten aus den relativ langen Zeiträumen, als Serbien Bestandteil verschiedener jugoslawischer Staaten war. Da Rechtsgrundsätze stets in einen Kontext eingebettet sind und ohne einen solchen nicht funktionieren können, muss zunächst einmal der gesamte Prozess der Verfassungsgründung in einem breiteren gesellschaftlich-historischen Kontext verortet werden, um die Anstrengungen der politischen und intellektuellen Eliten Serbiens erkennen zu können, die sich im Verlauf von nahezu zwei Jahrhunderten um die Bestimmung der besten Staatsform bemühten, die auf demokratischen Grundsätzen beruhen und stetiges Wirtschaftswachstum und kontinuierliche kulturelle Entwicklung gewähren sollte. Eine Analyse von Verfassungen in ihren Originalfassungen erbrachte die unzweideutige Erkenntnis, dass die Glaubensfreiheit in Serbien stetig gefördert wurde. Dies reichte von den Grundvoraussetzungen für die Ausübung der eigenen Religion, über die Bestimmung der Serbischen Orthodoxen 
DRUŠ. ISTRAŽ. ZAGREB GOD. 20 (2011), BR. 2 (112)

STR. 517-539

NOVAKOVIĆ, D.: POLOŽAJ CRKAYA.
Glaubensausübung für alle anderen Konfessionen, bis hin zur Anpassung diesbezüglicher Verfassungsrichtlinien an die wichtigsten Dokumente des internationalen Rechts und an die in der Europäischen Union geübte entsprechende Praxis. Eine Untersuchung der Verfassungen und der konkreten Umstände, in denen der serbische Staat selbstständig oder in Gemeinschaft mit anderen auftrat, zeigt die bewegte Entwicklung eines der bedeutendsten Abschnitte der serbischen Staatsgeschichte auf: Am Anfang stand eine auf orientalischen Werten gegründete Despotie ohne institutionelle Mechanismen zum Schutze des Lebens des Einzelnen und am Ende ein unabhängiger Staat, der sich entschlossen den besten demokratischen Traditionen anschließt, um seine Zukunft innerhalb des Vereinten Europa zu verwirklichen.

Schlüsselbegriffe: Serbien, Jugoslawien, Verfassungen, Glaubensfreiheit, Kirchen, Glaubensgemeinschaften 